SHARP-TAILED GROUSE

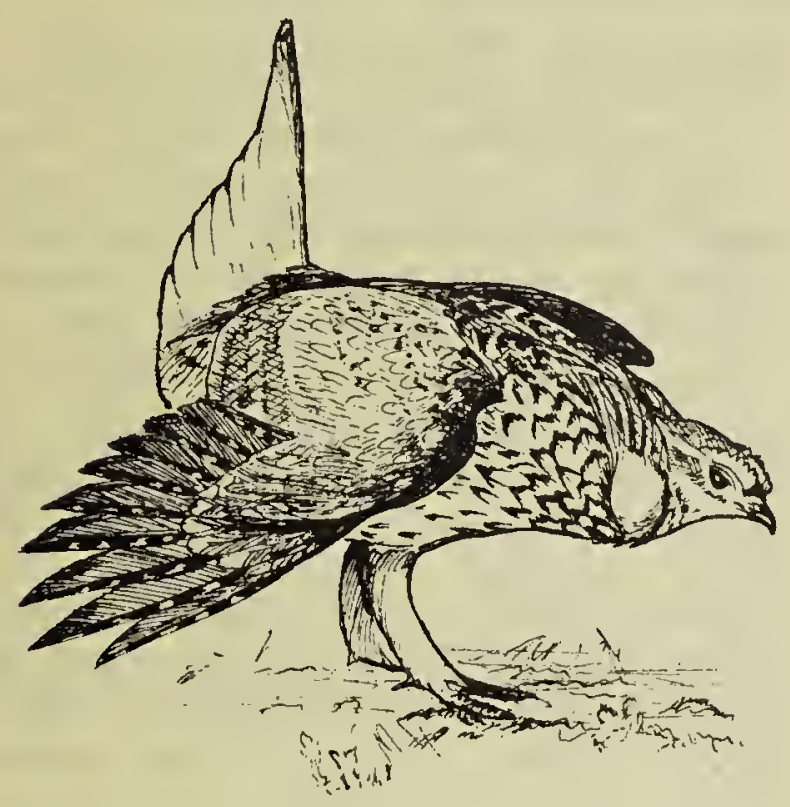

-F. W. Lahrman
PINNATED GROUSE

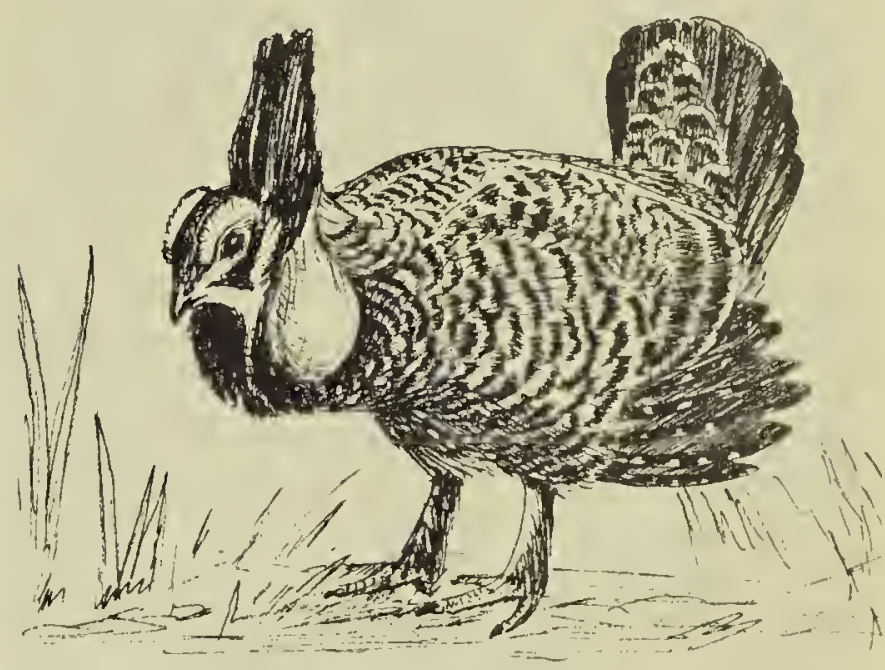

-F. W. Lahrman

\title{
The Pinnated Grouse
}

\section{By Dr. STUART HOUSTON}

F. N. Hamerstrom, Jr. of the Wisconsin Conservation Department is making a study of the Pinnated Grouse and is anxious to obtain all the information he can concerning the status of this species in Saskatchewan.

The Pinnated Grouse was not an original inhabitant of Saskatchewan, as was its near relative the Sharp-tailed Grouse. The Pinnated Grouse followed the advance of farming westward and at one time was fairly common in open grassy areas in Saskatchewan. However, partly because of more intensive cultivation and partly berause of factors unknown, the numbers of the Pinnated Grouse have decreased markedly in the last twenty or twenty-five years. In fact, there are people, like myself, who have only been studying birds for fifteen years, who have never, seen a Pinnated Grouse.

Both the Pinnated Grouse and the Sharp-tailed Grouse are commonly called "Prairie Chicken." The name correctly belongs only to the former, but in general usage the name is most commonly applied to the latter. Because of this confusion, as well as confusion with the Ruffed Grouse, most of the recent supposed reports of Pinnated Grouse in Saskatchewan are open to some question. The Pinnated Grouse is a rather dark bird, with heavy barring of its underparts and a rounded tail which is evenly dark in color. The Sharp-tailed Grouse is paler in color and has little v-marks on its breast and a narrow light-colored tail, that appears white in flight. The Ruffed Grouse is a woodland bird with a fan-shaped tail with a black band.

We are anxious to obtain information concerning this species in Saskatchewan, before it is completely extinct. If there are anly local areas regularly inhabited by this species, it might be possible to arrange for their protection. It would be appreciated if all readers would send the approximate date the Pinnated Grouse was last seen in their locality, with details as to numbers, to: Dr. Stuart Houston, Box 179, Sutherland, Sask. 